\title{
POPULATION BIOLOGY AND DIET OF THE SOUTHERN KINGCROAKER Menticirrhus americanus (LINNAEUS, 1758) (PERCIFORMES: SCIAENIDAE) IN CARAGUATATUBA BAY, SOUTHEASTERN BRAZIL
}

\author{
Alexander Turra ${ }^{1}$, Flávia Borges Santos ${ }^{2}$, Eduardo Bessa ${ }^{3}$, Wellington Silva Fernandez ${ }^{1, *}$, \\ Ligia Coletti Bernadochi ${ }^{4}$ and Márcia Regina Denadai ${ }^{4}$ \\ ${ }^{1}$ Instituto Oceanográfico da Universidade de São Paulo \\ (Praça do Oceanográfico, 191, 05508-120 São Paulo, SP, Brasil) \\ ${ }^{2}$ Universidade Estadual do Sudoeste da Bahia - Departamento de Ciências Naturais \\ (Estrada do Bem Querer, Km 04, 45083-900 Vitória da Conquista, BA, Brasil) \\ ${ }^{3}$ Instituto de Ciência Naturais e da Terra da Universidade do Estado de Mato Grosso \\ (Rodovia MT-358, Km 7, 78300-000 Tangara da Serra, MT, Brasil) \\ ${ }^{4}$ Centro Universitário Módulo \\ (Av. Frei Pacífico Wagner, 653, 11660-903 Caraguatatuba, SP, Brasil) \\ *Corresponding author: fernandez@usp.br
}

\begin{abstract}
A B STRACT
This study evaluated the spatio-temporal distribution, population biology and diet of Menticirrhus americanus in Caraguatatuba Bay. Samples were taken monthly between August 2003 and October 2004, by trawling in two previously selected areas. The northern area is more exposed to wave activity and is influenced by a river, functioning as a small estuary. In contrast, the southern area is relatively sheltered from wave energy and influenced to a lesser degree by smaller rivers. The fishes' length was measured, and the sex and gonadal stage macroscopically identified. The abundance of this species was compared between areas and among months. The diet was identified and quantified. M. americanus occurred in equal proportions in the two study areas, being most abundant in April 2004, followed by December 2003 and January 2004. The population was dominated by small immature individuals. The few individuals in maturation or mature that were captured showed no seasonal pattern of distribution. This species had a varied diet, feeding on worms (nemerteans, sipunculans and echiurans), mollusks (bivalves and cephalopods), polychaetes, crustaceans and fish. The presence of intact nematodes in the intestine suggests that these are parasites. The results demonstrated that $M$. americanus has a homogeneous spatial and temporal distribution in Caraguatatuba Bay, being uniformly distributed between the south and north areas as well as across the months. This species can be considered a carnivorous predator, showing a preference for consuming benthic sandy-beach species such as glycerids and other polychaetes, crustaceans, and bivalve siphons.
\end{abstract}

\section{RESUMO}

Este estudo teve como objetivo avaliar a distribuição espaço-temporal, biologia populacional e dieta de Menticirrhus americanus da baía de Caraguatatuba. Foram realizadas coletas mensais entre agosto de 2003 a outubro de 2004, utilizando redes de arrasto em duas áreas previamente selecionadas. A área norte é mais expostas à atividade de onda e é influenciada por um rio, constituindo um pequeno estuário. Por outro lado, a área sul é relativamente protegida da energia das ondas e sofre pouca influência dos rios. Os indivíduos coletados foram medidos e identificados macroscopicamente quanto ao sexo e o estádio gonadal. A abundância da espécie foi comparada entre as áreas e entre os meses de coleta. Para a dieta os itens alimentares encontrados foram identificados e quantificados. M. americanus apresentou proporções equivalentes nas duas áreas de estudo, sendo mais abundante em abril de 2004, seguido por dezembro de 2003 e janeiro de 2004. A população região é composta por indivíduos imaturos, e os poucos indivíduos maduros ou em maturação capturados não apresentaram padrão de distribuição ao longo do ano. A espécie mostrou uma dieta variada, alimentando-se de vermes (nemertideos, sipúnculos e equiúros), moluscos (bivalves e cefalópodes), poliquetas, crustáceos e peixes. A presença de nematóides intactos na porção do intestino sugere uma relação parasitária. Os resultados demonstraram que os indivíduos de Menticirrhus americanus estiveram uniformemente distribuídos nas áreas norte e sul e também ao longo do ano. A espécie pode ser considerada predadora e carnívora, mostrando preferência na alimentação por espécies bentônicas de fundos não consolidados, tais como geicerídeos e outros poliquetas, crustáceos e sifões de bivalves.

Descriptors: Feeding, Reproduction, Spatio-temporal distribution, Betara, São Paulo.

Descritores: Alimentação, Reprodução, Distribuição espaço-temporal, Betara, São Paulo. 


\section{INTRODUCTION}

The sciaenid genus Menticirrhus comprises nine species that inhabit the tropical and temperate waters of the eastern Pacific and western Atlantic (BRAUN; FONTOURA, 2004). Two species are found in Brazilian waters: M. americanus (Linnaeus, 1758) and M. littoralis (Holbrook, 1847) (MENEZES; FIGUEIREDO, 1980; CARVALHO-FILHO, 1999; FISCHER et al., 2004).

The southern kingcroaker Menticirrhus americanus, popularly known in Brazil as "Betara", "Papa-terra" or "Perna-de-Moça", is distributed over the western Atlantic from $41^{\circ} \mathrm{N}$ to $51^{\circ} \mathrm{S}$ (CHAO, 1978), from Cape Cod (USA) to Argentina (CASATTI; MENEZES, 2003). It may reach $50 \mathrm{~cm}$ in length (MENEZES; FIGUEIREDO, 1980; CERVIGÓN, 1993) and 1,070 $\mathrm{g}$ in weight (IGFA, 2001). It occurs in coastal waters down to depths of 85 m (MENEZES; FIGUEIREDO, 1980; CARVALHOFILHO, 1999), generally on sandy and muddy bottoms, but also on hard-sand bottoms. Although this species is observed in hypersaline lagoons, young individuals often occur in low-salinity waters (CHAO, 1978); the inner demersal zone, such as estuaries, is used by this species for reproduction and growth. According, M. americanus belongs to the marineestuarine ecological, the demersal vertical, the benthicfish feeding, and the summer-reproduction guilds.

The biology of $M$. americanus on the southeastern and southern Brazilian coast has been studied by several investigators. Ecological aspects have been analyzed by Gianini; Paiva-Filho (1992) in São Paulo and by Haluch et al. (2011) on the Santa Catarina coast. The diet has been evaluated by Juca-Chagas (1997) and Rondinelli et al. (2007) on the São Paulo coast, by Lunardon et al. (1991) in Paraná, and by Haluch et al. (2009) in Santa Catarina. Its reproductive conditions have been assessed by Matsuura; Nakatani (1979) in São Paulo, and Muniz; Chaves (2008) and Haluch et al. (2011) in Santa Catarina. The condition factor has been measured by Lunardon-Branco; Branco (1993) on the Paraná coast. Other studies have examined its reproduction (SMITH; WERNER, 1985; HARDING; CHITTENDEN, 1987), movements and population dynamics (HARDING; CHITTENDEN, 1987) in the North Atlantic.

However, knowledge of $M$. americanus as well as of other members of theichthyofauna in Caraguatatuba Bay, is still lacking. A pioneer project in this area has been studying the mega-epifauna populations as part of an effort to understand this ecosystem. Caraguatatuba Bay is nowhere more than 5 $m$ deep, and the fishes in this environment have been but little studied. The region has been undergoing anthropic changes, such as the installation of gas pipelines, the construction of a gas treatment facility and the expansion of São Sebastião Port. Complementarily, State Decree no. 49,215 (December 7, 2004), which relates to the Exclusive Economic Zone (ZEE) of São Paulo's northern coast, forbids trawling in bay areas. The present study concerns the spatio-temporal distribution, size distribution, reproductive aspects, and diet of $M$. americanus, one of the most important components of Caraguatatuba Bay's ichthyofauna. The observations may provide helpful information for future research and management plans for Caraguatatuba Bay, because this study was undertaken prior to the impacts felt in this area.

\section{Material and Methods}

Study Area

Caraguatatuba Bay $\left(23^{\circ} 37^{\prime} \mathrm{S}\right.$ to $23^{\circ} 44^{\prime} \mathrm{S}$ and $45^{\circ} 24^{\prime} \mathrm{W}$ to $45^{\circ} 26^{\prime} \mathrm{W}$ ) has a total extent of about 16 $\mathrm{km}$ (Fig. 1). From among the sandy beaches on the bay, two areas each of $2 \times 2 \mathrm{~km}$, homogeneous but distinct from each other, were selected for this study (Fig. 1). The locations of these areas were selected in order to avoid any great influence of the local rivers (Juqueriquerê, Lagoa and Santo Antônio) on them. The first, the South area, extends from Porto Novo to Palmeiras beaches and has a gentler slope; it is more exposed to wave activity and is influenced by the Juqueriquerê River, functioning as a small estuary. The North area, extending from Indaiá to Centro beaches, has a steeper slope; it is relatively sheltered from wave energy and is relatively little influenced by the smaller rivers (Lagoa and Santo Antônio).

\section{Sampling Methods}

Monthly samples were taken between August 2003 and October 2004. Three sampling stations were randomly selected in each area, South and North, from among 200 possible sites; i.e., from the total $2000-\mathrm{m}$ length of the beach divided into $10-\mathrm{m}$ intervals. The positions of the stations were stored in the GPS at MLW (mean low water).

At each station, a trawl $800 \mathrm{~m}$ long was undertaken, perpendicular to the beach and beginning at a point $800 \mathrm{~m}$ from it, from a fishing boat (class $\mathrm{G} 2 \mathrm{M}, 11 \mathrm{~m}$ long with a 22-HP engine). This interval is equivalent to a depth of from 1 to $4 \mathrm{~m}$. The trawl speed was 1 knot. The trawls were performed using two otter trawls with a mesh size of $2.0 \mathrm{~cm}$, mouth aperture $1.6 \mathrm{~m}$ high and $6.0 \mathrm{~m}$ wide, and bag depth of $3.5 \mathrm{~m}$. 


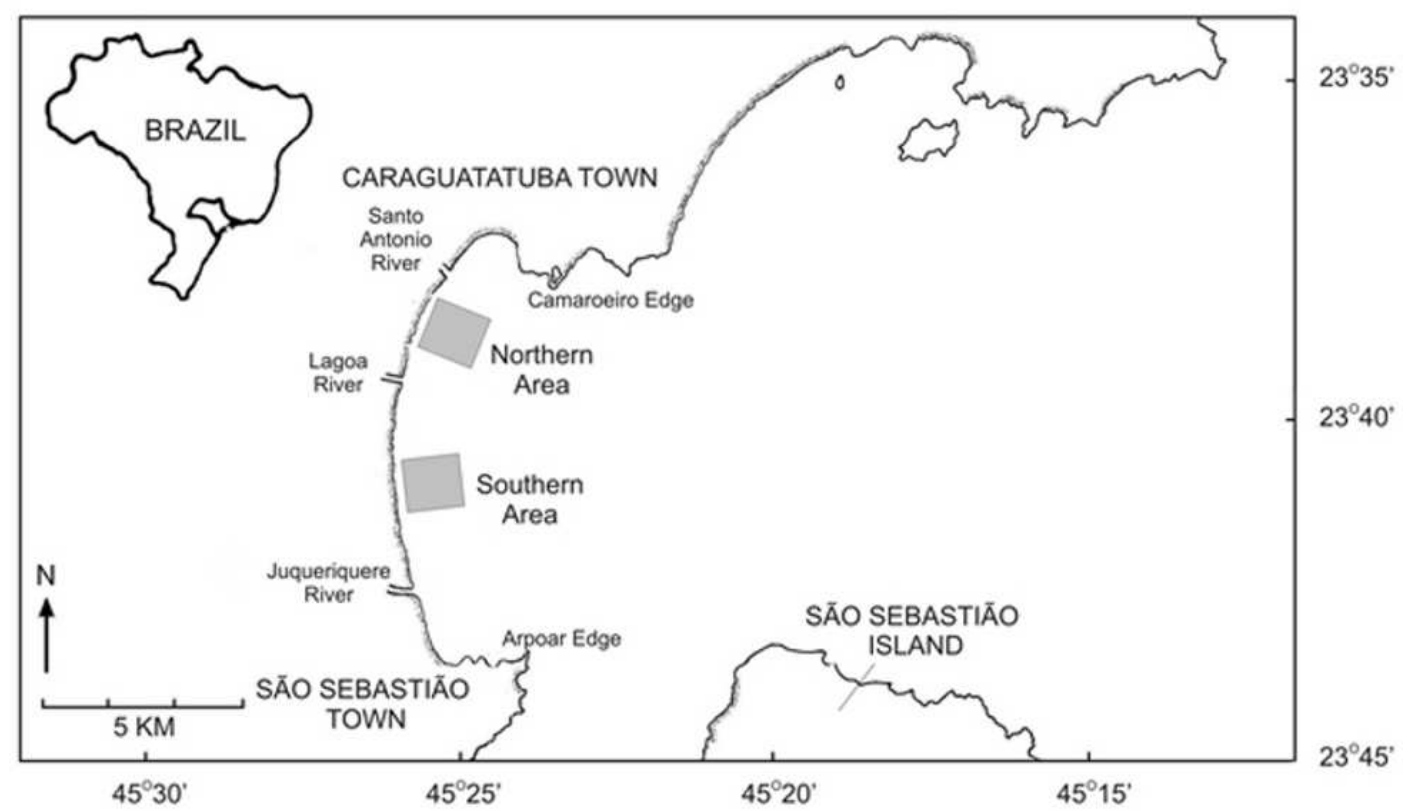

Fig. 1. Caraguatatuba Bay. The study areas (South and North) are represented by the gray squares.

The fish were removed from the net and immediately preserved in a $10 \%$ formalin solution in order to halt enzyme action and preserve the gut contents (UIEDA; CASTRO, 1999). The samples were identified and stored in plastic receptacles. In the laboratory, the specimens were identified to species level and transferred to $70 \%$ ethanol.

\section{Population Analysis and Diet}

All the individuals of $M$. americanus obtained in the samples were measured for total length (TL) as well as standard length (SL), which is the distance between the anterior head edge and the base of the caudal fin (beginning of caudal fin rays (FIGUEIREDO; MENEZES, 1978).

A total of 160 individuals of $M$. americanus were sorted from the 468 specimens obtained in the study period, using a random-numbers table. An abdominal-ventro-sagittal incision was made from the anal aperture to the pelvic-fin insertions. The gut and gonads were removed. The gonads were inspected, sexed, and macroscopically classified according to the maturation categories from Vazzoler (1996).

The gut length (distance between the beginning of the esophagus and the end of the rectum; digestive tube length or DTL) was measured in order to establish the DTL/SL (gut length/standard length) ratio, and to evaluate a possible relationship with the diet of M. americanus (KNÖPPEL, 1970). The guts were preserved in $70 \%$ ethanol until the analysis of their contents.

The guts were divided into two portions; the first consisted of the pharynx, esophagus and stomach, and the second of the intestine and rectum, due to the different degrees of digestion of the contents in each portion. Finally, the contents of each gut were identified. The volume of each item was measured according to the methodologies of Bemvenuti (1990).

\section{Data Analysis}

The mean number of individuals $( \pm \mathrm{SE})$ of $M$. americanus was calculated for the study months and areas (South and North). The sum of the areas was also calculated. Two-way ANOVA was performed to evaluate differences in the spatial (areas) and temporal (months) distribution. A histogram illustrating the relative frequency distribution of the size classes (standard length) of $M$. americanus was constructed for the total population sample. A chi-squared test was performed to determine the male:female sex ratio, with $\alpha=0.05$.

The diet of $M$. americanus was analyzed by the frequency of occurrence $(\mathrm{F} \%)$, percent volume $(\mathrm{V} \%)$ and index of alimentary importance $\left(\mathrm{IA}_{\mathrm{i}}\right)$, separately for the stomach and intestine contents. The index of alimentary importance was calculated by a modification of the method used by Kawakami; Vazzoler (1980) based on the frequency of occurrence 
and on the percent volume of each item. Only the stomach contents were considered for a seasonal analysis of the frequency of occurrence and volume.

\section{RESULTS}

Menticirrhus americanus occurred in equivalent proportions in the two study areas, South and North $(\mathrm{F}=3.486, \mathrm{df}=1, \mathrm{p}=0.067$ - Fig. 2). This fish were most abundant in April 2004, followed by December 2003 and January $2004(\mathrm{~F}=13.614, \mathrm{df}=13$, $\mathrm{p}<0,001$ ) (Fig. 2). The temporal distribution (months) appeared to be dependent on the spatial distribution (area) $(\mathrm{F}=0.803 ; \mathrm{df}=13 ; \mathrm{p}=0.654)$.

The individuals of $M$. americanus in Caraguatatuba Bay had a mean total length of $119 \pm$ $32 \mathrm{~mm}(\min .-\max .=50-320 \mathrm{~mm})$, mean standard length of $97 \pm 27 \mathrm{~mm}(\min .-\max .=40-260 \mathrm{~mm})$ and mean gut length of $71 \pm 17 \mathrm{~mm}(43-180 \mathrm{~mm})$. A histogram of size classes (standard length - Fig. 3) revealed a high abundance $(85 \%)$ of individuals between 65 and $125 \mathrm{~mm}$.
Almost $70 \%$ of the 160 individuals that had the gonads examined were "immature", i.e., the sex could not be identified macroscopically. Of the 49 individuals $(30 \%)$ that had their sex identified, $26.5 \%$ (13 inds.) were females and $73.5 \%$ (36 inds.) were males $\left(\chi^{2}=10.796 ; \mathrm{df}=1 ; \mathrm{p}<0.005\right)$. Of the females, $23.1 \%$ (3 inds.) were "in maturation" and $76.9 \%$ (10 inds.) "mature". Of the males, $83.3 \%$ (30 inds.) were "in maturation" and $16.7 \%$ (6 inds.) "mature". Of the individuals "in maturation" or "mature", $84.6 \%$ of the females and $65.6 \%$ of the males occurred in the South area. The proportions of the younger immature individuals were $53.5 \%$ and $46.5 \%$ for the South and North areas, respectively. The smallest males in maturation and mature had, respectively, total lengths of $95 \mathrm{~cm}$ and $141 \mathrm{~mm}$, and the smallest females measured, respectively, 136 and $157 \mathrm{~mm}$. Despite the small number of sexed individuals, there was a tendency for the number of individuals in maturation and mature to increase from autumn to winter, followed by a reduction in spring and summer (Fig. 4).

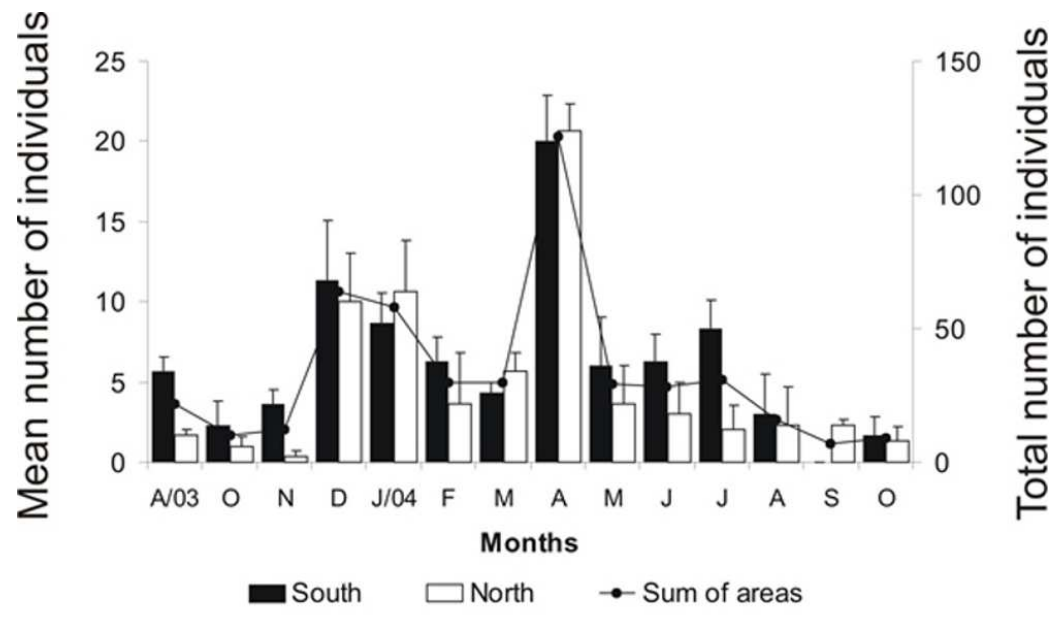

Fig. 2. Menticirrhus americanus. Monthly mean (+ standard error) number of individuals/trawling in each of the two study areas (South and North) and monthly total number of individuals in the two areas combined

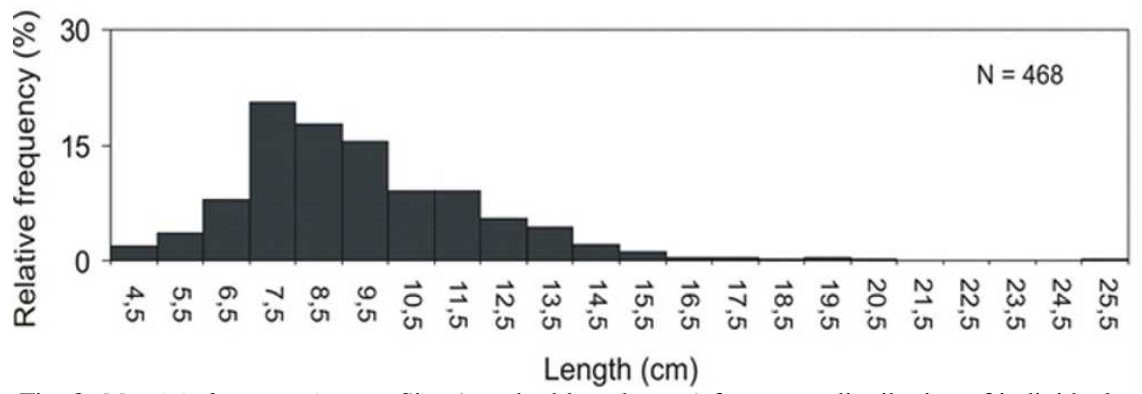

Fig. 3. Menticirrhus americanus. Size (standard length $-\mathrm{cm}$ ) frequency distribution of individuals in the study period. 
This species consumed 14 food items (Table 1). All of these items were found in the stomach, while only 3 (Echiura, Polychaeta and Caprella sp.) were found in the intestinal portion. The most frequent and voluminous items in the stomach were polychaetes (unidentified and Glyceridae). As a food item of secondary importance, the amphipod Caprella sp. was more frequent than unidentified crustaceans, which occupied more volume than the amphipod. In the intestine, nematodes were present in almost half of the individuals examined, and the most frequent and voluminous item was Caprella.

The seasonal analysis of the stomach contents showed few variations in the frequency of occurrence during the study period (Fig. 5). The glycerids had relatively higher frequencies in autumnwinter and lower in spring-summer, while the unidentified polychaetes had higher values in springsummer. No bivalve siphons were ingested in the autumn, with a relatively higher number observed in the diet in the winter.

Table 1. Menticirrhus americanus. Frequency of occurrence (F\%), percentage volume (V\%) and index of alimentary importance $\left(\mathrm{IA}_{\mathrm{i}}\right)$. Total number of individuals $(\mathrm{N}=160)$, individuals with empty gut $(\mathrm{Ne}=21)$, mean standard length $(\mathrm{SL}=9.7$ $\mathrm{cm})$, gut length and standard length ratio (DTL/SL=0.71).

\begin{tabular}{|c|c|c|c|c|c|c|}
\hline \multirow[b]{2}{*}{ Food items } & \multicolumn{3}{|c|}{ Stomach } & \multicolumn{3}{|c|}{ Intestine } \\
\hline & F (\%) & $\mathrm{V}(\%)$ & $\mathbf{I A}_{\mathbf{i}}(\%)$ & F (\%) & $\mathrm{V}(\%)$ & $\mathbf{I A}_{\mathbf{i}}(\%)$ \\
\hline \multicolumn{7}{|l|}{ Phylum Nemertea } \\
\hline Nemertea - unidentified & 13.67 & 11.29 & 5.785 & 0.00 & 0.00 & 0.000 \\
\hline \multicolumn{7}{|l|}{ Phylum Sipuncula } \\
\hline Sipuncula - unidentified & 0.72 & 0.06 & 0.002 & 0.00 & 0.00 & 0.000 \\
\hline \multicolumn{7}{|l|}{ Phylum Echiura } \\
\hline Echiura - unidentified & 10.07 & 0.80 & 0.303 & 4.17 & 1.11 & 0.053 \\
\hline \multicolumn{7}{|l|}{ Phylum Mollusca } \\
\hline \multicolumn{7}{|l|}{ Class Bivalvia } \\
\hline Bivalve siphons & 17.27 & 2.92 & 1.887 & 0.00 & 0.00 & 0.000 \\
\hline \multicolumn{7}{|l|}{ Class Cephalopoda } \\
\hline Squid - unidentified & 0.72 & 0.04 & 0.001 & 0.00 & 0.00 & 0.000 \\
\hline \multicolumn{7}{|l|}{ Phylum Annelida } \\
\hline Polychaetes - unidentified (other than Glyceridae) & 39.57 & 28.42 & 42.167 & 4.17 & 3.33 & 0.158 \\
\hline Glyceridae & 41.01 & 16.74 & 25.743 & 0.00 & 0.00 & 0.000 \\
\hline \multicolumn{7}{|l|}{ Phylum Crustacea } \\
\hline Crustacea - unidentified (other than Brachyura and Caprella sp.) & 24.46 & 19.32 & 17.721 & 0.00 & 0.00 & 0.000 \\
\hline \multicolumn{7}{|l|}{ Class Malacostraca } \\
\hline \multicolumn{7}{|l|}{ Order Decapoda } \\
\hline Crab - unidentified & 5.04 & 17.08 & 3.225 & 0.00 & 0.00 & 0.000 \\
\hline \multicolumn{7}{|l|}{ Order Amphipoda } \\
\hline Amphipod tubes & 0.72 & 0.07 & 0.002 & 0.00 & 0.00 & 0.000 \\
\hline Caprellasp. & 27.34 & 3.08 & 3.160 & 91.67 & 95.56 & 99.789 \\
\hline \multicolumn{7}{|l|}{ Phylum Chordata } \\
\hline \multicolumn{7}{|l|}{ Class Pisces } \\
\hline Fish scales & 0.72 & 0.06 & 0.002 & 0.00 & 0.00 & 0.000 \\
\hline Fish - unidentified (other than sole) & 0.72 & 0.04 & 0.001 & 0.00 & 0.00 & 0.000 \\
\hline Sole & 0.72 & 0.07 & 0.002 & 0.00 & 0.00 & 0.000 \\
\hline
\end{tabular}


The volumes of the items showed few seasonal differences (Fig. 6). The polychaetes had higher volumes in autumn-winter than in springsummer, while the volume of glycerids was lowest in winter and highest in spring. The crustaceans had lower volumes in the autumn and spring. The brachyurans showed the lowest volume in the autumn and the highest in the summer. The variation in the composition of the brachyurans is due to their occasional, although voluminous, occurrence.

Fig. 5. Menticirrhus americanus. Frequency of occurrence of food items in the stomach in different seasons. $($ Nem $=$ unidentified Nemertea; $\mathrm{Sip}=$ Sipuncula; Ech = Echiura; BS = Bivalve siphons; Squ = Squid; Pol = unidentified Polychaete; Gly = Glyceridae polychaetes; $\mathrm{Cru}=$ unidentified Crustacean; Bra = Brachyura; Amp = Amphipod tubes; Cap = Caprella sp.; FS - Fish scale; Fish $=$ unidentified Fish; Sole $=$ Sole)
Figure 7 illustrates the lack of dominance of any item in the diet of $M$. americanus. The unidentified polychaetes were frequent and relatively voluminous. The glicerid polychaetes were frequent, but not as voluminous. Unidentified crustaceans had medium frequency and volume, while the brachyurans were voluminous but occurred in low frequency. Nemertineans and the amphipod Caprella had lower alimentary importance; however, the amphipods were frequent.
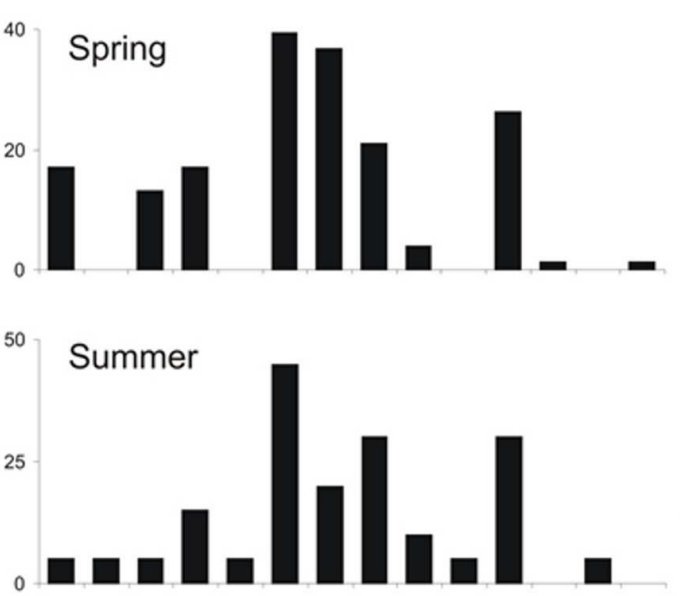

${ }^{60}$ Autumn

30

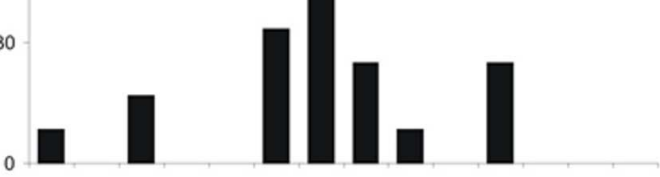

Wo Winter

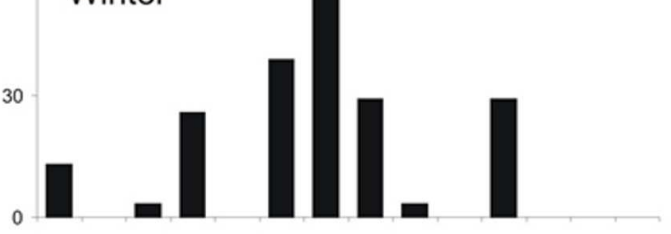

50

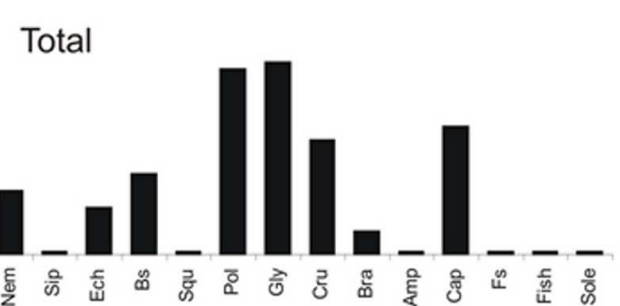

Diet items 


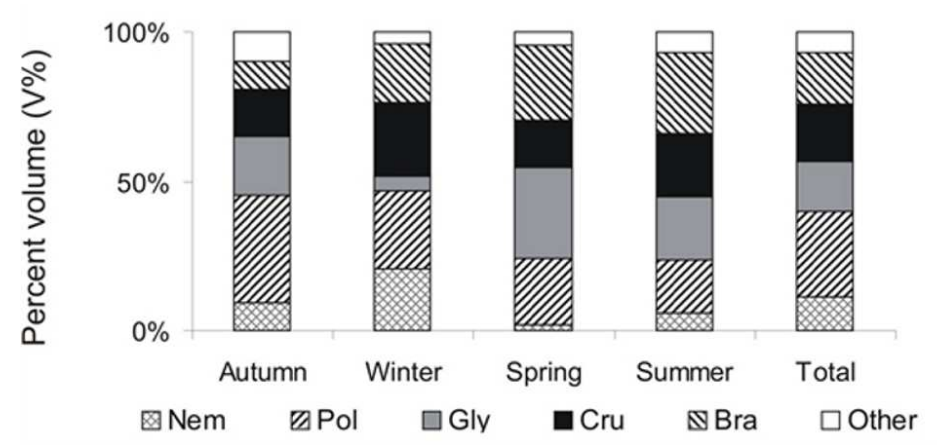

Fig. 6. Menticirrhus americanus. Percentage volume of the most voluminous food items in the stomach. $(\mathrm{Nem}=$ unidentified Nemertea; Pol $=$ unidentified Polychaete; Gly = Glyceridae polychaetes; Cru = unidentified Crustacean; Bra $=$ Brachyura; Other $=$ other items)
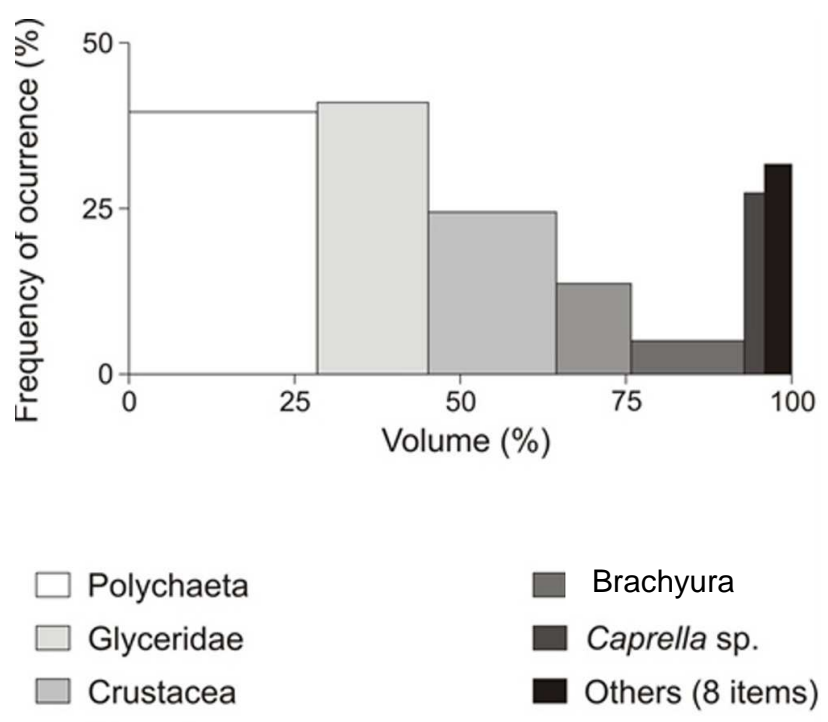

Nemertinea

Fig. 7. Menticirrhus americanus.Relationship between the frequency of occurrence and the percentage volume of the items with greater food importance in the stomach.

\section{DisCUSSION}

Menticirrhus americanus showed a regular spatio-temporal distribution in Caraguatatuba Bay, being uniformly distributed between the South and North areas as well as over the months, with a peak of abundance in April 2004. The spatial homogeneity may be explained by the lack of difference between the North and South areas in relation to factors that determine this species' distribution, such as muddy or sandy bottoms (CHAO, 1978) and depths shallower than $9 \mathrm{~m}$ (HARDING; CHITTENDEN, 1987 and GIANNINI; PAIVA-FILHO, 1992). The low salinity, due to input from the rivers, may have accounted for the predominance of juveniles (CHAO, 1978). This predominance of juveniles may also be explained if $M$. americanus shows a similar depth gradient to that observed for the congener Menticirrhus littoralis by braun and Fontoura (2004) in Rio Grande do Sul coastal waters, where larger individuals inhabit deeper water and move to the coast for spawning.

The mean size of the individuals of $M$. americanus in Caraguatatuba Bay was $119 \mathrm{~mm}$ TL (50 $-320 \mathrm{~mm}$ ) and most of the individuals sampled (97\%) did not reach $145 \mathrm{~mm}$ TL. This may explain why few 
mature individuals were collected, since first maturation has been found to occur at $150-220 \mathrm{~mm}$ (HARDING; CHITTENDEN, 1987) after 12-14 months in the Gulf of Mexico; at $140 \mathrm{~mm}$ (GIANNINI; PAIVA-FILHO, 1992) on the coast of São Paulo; or $135 \mathrm{~mm}$ for males and $190 \mathrm{~mm}$ for females (SMITH; WENNER, 1985) in the North Atlantic.

According, M. americanus uses estuaries as nurseries, but also for reproducing. In fact, the majority $(65 \%)$ of the 49 individuals for which the sex could be identified in this study, i.e. with the gonads mature or in maturation, occurred in the South area, which is more influenced by the river. Of these fish, the majority of females (82\%) had gonads in the mature stage. This pattern suggests that estuarine conditions such as those in the South area are chosen by this species for reproducing. Additionally, the young immature individuals did not exhibit any preference for either of the two areas.

The increased numbers of mature individuals of M. americanus in Caraguatatuba Bay in winter suggest that reproductive activity is more intense during this season. Matsuura and Nakatani (1979), Smith; Wenner (1985) and Haluch et al. (2011) observed reproductive activity in the summer on the São Paulo coast, in the North Atlantic (USA) and in Santa Catarina state, respectively. Muniz; Chaves (2008) observed the spawning period in the spring-summer in São Paulo State. Harding and Chittenden (1987) found an extensive period of reproduction in the Gulf of Mexico, from February to November (winter to autumn), with two peaks, in spring and autumn. Lunardon-Branco and Branco (1993) observed reproduction during autumn, winter and spring in Paraná, characterized this species as a member of the summer reproductive guild in the Paranaguá estuarine complex. Furthermore, Braun and Fontoura (2004) observed, for the congener $M$. littoralis, a reproductive period between September and March (spring-summer) in southern Brazil. These marked differences in the reproductive periods may be a factor of the differences in climate, as proposed by Braun and Fontoura (2004).

Menticirrhus americanus showed a preference for consuming benthic sandy-beach species, such as glycerids and other polychaetes, crustaceans, and bivalve siphons. This may, in part, explain the wide distribution of this species along the Caraguatatuba Bay sandy beaches, rather than being restricted to the estuarine region in the South area, as mentioned in the current literature on the species (CHAO, 1978; HARDING; CHITTENDEN, 1987; GIANNINI; PAIVA-FILHO, 1992). In general, in this bay $M$. americanus has a varied diet, feeding on worms (nemerteans, sipunculans and echiurans), mollusks (bivalves and cephalopods), polychaetes, crustaceans and fish. Thus, this species can be considered a carnivorous predator, as also indicated by the digestive tube length/standard length ratio $(\mathrm{DTL} / \mathrm{SL}=0.71)$. Ratios less than 1.0 suggest a predatory habit, while values higher than 1.0 refer to omnivores (KNÖPPEL, 1970). The literature on this species refers to the crustaceans, polychaetes, mollusks, fish, cephalochordates and plants (LUNARDON et al., 1991; MCLACHLAN et al., 1996; CHAVES; UMBRIA, 2003; RONDINELLI et al., 2007) as important dietary items. Rondinelli et al. (2007) reported a preponderance of crustaceans in the diet; of crustaceans and cephalochordates, and Chaves; Umbria (2003), of crustaceans (non-brachiurans) and fish. Thus, according to the literature, crustaceans dominate in the diet of $M$. americanus, in contrast to the data obtained in this study, in which the polychaetes were the most important item. However, Haluch et al. (2009) observed the great importance of polychaetes in the diet of small individuals $(<121$ $\mathrm{mm}$ ), which is the size range of most individuals sampled in Caraguatatuba Bay. This species as a benthic consumer, which is corroborated by the results presented here. The mouth anatomy (terminal and oblique) contributes to this feeding habit (CHAO, 1978; JUCÁ-CHAGAS, 1997). M. americanus has a subterminal mouth, morphologically adapted to the benthic-carnivorous feeding habit, as much as for foraging on polychaetes in the sediment.

Glycerid polychaetes were the most important items in the diet of this species in numerical terms. Crustacean fragments were also commonly identified in the diet, confirming the importance of this group for M. americanus, as can be seen from the voluminous crabs and numerous caprellids. Nemerteans, which have never before been observed in the diet of this fish, were of relatively great importance in the stomach contents. McLachlan et al. (1996) observed that this species eats the bivalve Tivela mactroides in Venezuela. This bivalve is highly abundant in the study area (DENADAI et al., 2005), but only bivalve siphons, probably from $T$. mactroides, were observed in the diet of $M$. americanus. This grazing habit had previously been described for the congener $M$. undulates, which feeds on siphons of $T$. stultorum (O'BRIEN; VALLE, 2000). Contrary to the literature on this species, fish were relatively unimportant in its diet.

The small seasonal variation in the diet of M. americanus in Caraguatatuba Bay may reflect the unlimited resources available for this species there, as well as a possible opportunistic habit, by which a variety of food items is ingested. Haluch et al. (2009), on the other hand, observed wide seasonal variations in the diet of $M$. americanus in Santa Catarina, related to the food availability and faunal migrations, leading to plasticity in the diet. 
High frequencies of animal-derived organic matter were detected in the gut of this fish, but were not included in the analysis, because this organic matter is an artifact of its feeding rhythm and foraging environment, rather than reflecting a detritivorous habit.

Nematodes were present in almost $50 \%$ of the intestines examined, with a mean of 2.35 individuals/intestine. The integrity of these organisms in the intestinal portion and their soft body wall, which is easily digestible, lead us to presume that the nematodes are intestinal parasites of $M$. americanus. Nematodes are commonly found as parasites in the intestine of sciaenid fishes (PEREIRA et al., 2002; ROMERO et al., 2008). Nematodes were also observed in the stomach contents of M. americanus, indicating a need for intensification of studies on this species, to confirm this hypothesis.

The results presented above demonstrated that $M$. americanus had a regular spatio-temporal distribution in Caraguatatuba Bay, being uniformly distributed between the South and North areas as well as over the months, with a peak of abundance in April 2004. This species may be considered a carnivorous predator, showing a preference for consuming benthic sandy-beach species, such as glycerids and other polychaetes, crustaceans, and bivalve siphons.

\section{ACKNOWLEDGEMENTs}

This work was partially supported by the State of São Paulo Research Foundation (FAPESP) within the BIOTA/FAPESP - The Biodiversity Virtual Institute Program (www.biotasp.org.br). We thank FAPESP also for a grant from the "Programa Jovem Pesquisador em Centro Emergente" awarded to M.R.D (Proc. Fapesp No. 05/60041-6). We also thank CNPq for the grant of a scholarship to L.C.B. (Proc. No. 504119/2007-9). The Project Aware Foundation supported parts of this research project. We are grateful for the logistical support provided by the Instituto Costa Brasilis - Desenvolvimento SócioAmbiental as well as by the Centro Universitário da Fundação de Ensino Octávio Bastos.

\section{REFERENCES}

BEMVENUTI, M. A. Hábitos alimentares de peixes-rei (Atherinidae) na região estuarina da Lagoa dos Patos. Atlântica, v. 12, p. 79-102, 1990.

BRAUN, A. S.; FONTOURA, N.F. Reproductive biology of Menticirrhus littoralis in southern Brazil (Actinopterygii: Perciformes: Sciaenidae). Neotrop. Ichthyol., v. 2, n. 1, p. 31-36, 2004.

CARVAlHO FILHO, A. Peixes da Costa Brasileira. 3rd ed. São Paulo: Melro, 1999. 318 p.

CASSATTTI, L.; MENEZES, N. A. In: MENEZES, N. A.; BUCKUP, P. A.; FIGUEIREDO, J. L.; MOURA, R. L.
Catálogo das espécies de peixes marinhos do Brasil. São Paulo: Museu de Zoologia da Universidade de São Paulo, 2003. $160 \mathrm{p}$.

CERVIGÓN, F. Los peces marinos de Venezuela. Caracas: Fundación Científica Los Roques, 1993. V. 2, 497 p.

CHAO, L. N. Sciaenidae. 94 p. In: FISCHER, W. (Ed.). FAO Species Identification Sheets for Fishery Purposes. West Atlantic (Fishing Area 31). Rome: FAO, 1978. V.4, 94 p.

CHAVES P. T. C.; UMBRIA, S. C. Changes in the diet composition of transitory fishes in coastal systems, Estuary and continental Shelf. Braz. Arch. Biol. Technol., v. 46, p. 41-46, 2003.

DENADAI, M. R.; AMARAL, A. C. Z.; TURRA, A. Alongand across-shore components of the spatial distribution of the clam Tivela mactroides (Born 1778) (Bivalvia, Veneridae). J. Nat. Hist., v. 39, n. 36, p. 3275-3295, 2005.

FIGUEIREDO, J. L.; MENEZES, N. A. Manual de peixes marinhos do sudeste do Brasil. V. Teleostei (1). São Paulo: Museu de Zoologia da Universidade de São Paulo, 1978, 110 p.

FISCHER, L. G; PEREIRA, L. E. D.; VIEIRA, J. P. Peixes estuarinos e costeiros. Rio Grande, RS: Editora Ecoscientia, 2004. 126 p. (Série Biodiversidade do Atlântico do Sudeste).

GIANNINI, R.; PAIVA-FILHO, A. M. Aspectos da bioecologia de Menticirrhus americanus (Teleostei, Sciaenidae) na Baia de Santos, SP, Brasil. Bol. Inst. Pesca, v. 19, p. 1-15, 1992.

HALUCH, C. F.; FREITAS, M. O.; CORRÊA, M. F. M.; ABILHOA, V. Variação sazonal e mudanças ontogênicas na dieta de Menticirrhus americanus (Linnaeus, 1758) (Teleostei, Sciaenidae) na baía de Ubatuba-Enseada, Santa Catarina, Brasil. Pan-Am. J. Aquat. Sci., v. 4, n. 3, p. 347-356, 2009.

HALUCH, C. F.; ABILHOA, V.; FREITAS, M. O.; CORRÊA, M.F.M.; HOSTIM-SILVA, M. Estrutura populacional e biologia reprodutiva de Menticirrhus americanus (Linnaeus, 1758) (Teleostei, Sciaenidae) na baía de Ubatuba-Enseada, Santa Catarina, Brasil. Biotemas, v. 24, n. 1, p. 47-59, 2011.

HARDING, S. M.; CHITTENDEN, M. E. Reproduction, movements and population dynamics of the southern kingfish Menticirrhus americanus in the northwestern Gulf of Mexico. NOAA Tech. Rep. NMFS., v. 49, p. 121, 1987.

IGFA. Database of IGFA angling records until 2001. Fort Lauderdale: IGFA. Available in <http//www.igfa.org>, accessed 18 July 2011.

KAWAKAMI, E.; VAZZOLER, G. Método gráfico e estimativa de índice alimentar aplicado no estudo de alimentação de peixes. Bolm Inst. Oceanogr., v. 29, p. 205-207, 1980.

KNÖPPEL, H. A. Food of Central Amazonian fishes: contribution to the nutrient-ecology of Amazonian rain forest streams. Amazoniana, v. 2, p. 257-352, 1970.

LUNARDON, M. J.; SILVA, J. DE L.; VERANI, J. R.; BRANCO, J. O. Comportamento alimentar de Menticirrhus americanus (Linnaeus, 1758) (Perciformes: Sciaenidae) no litoral do Paraná, Brasil. Arq. Biol. Tecnol.,v. 34, n. 3/4, p. 487-502, 1991. 
LUNARDON-BRANCO, M. J.; BRANCO, J. O. Relação Peso/Comprimento e fator de Condição de Menticirrhus americanus (Pisces, Sciaenidae) na Baía de Paranaguá e adjacência, Brasil. Arq. Biol. Tecnol., v. 36, n. 3, p. 505511, 1993

MATSUURA, Y.; NAKATANI, K. Ocorrência de larvas e jovens de peixes na Ilha Anchieta (SP), com algumas anotações sobre a morfologia da castanha, Umbrina coroides Cuvier, 1930. Bolm Inst. Ocean., v. 28, n. 1, p. 165-183, 1979.

MCLACHLAN, A.; DUGAN, J. E.; DEFEO, O.; ANSELL, A. D.; HUBBARD, D. M.; JARAMILLO, E.; PENCHASZADEH, P. E. Beach clam fisheries. Oceanogr. Mar. Biol. Ann. Rev., v. 34, p. 163-232, 1996.

MENEZES, N.; FIGUEIREDO, J. L. Manual de peixes marinhos do sudeste do Brasil. IV. Teleostei (3). São Paulo: Museu de Zoologia da Universidade de São Paulo, 1980, 196 p.

MUNIZ, E. R.; CHAVES, P. T. C. Condição reprodutiva da betara preta, Menticirrhus americanus (Teleostei, Sciaenidae), na pesca realizada no litoral norte de Santa Catarina, Brasil. Acta Sci. Biol. Sci., v. 30, n. 4, p. 339344, 2008

O'BRIEN, J. W.; VALLE, C. F. Food habits of California corbina in southern California. Calif.Fish Game, v. 86 , p. 136-148, 2000.

PEREIRA, J. JR.; COSTA, M. A. S.; TUBINO, V. R. Indices parasitológicos de Cucullanidae (Nematoda: Seratoidea) em Micropogonias furnieri (Desmarest, 1823) no litoral do rio Grande do Sul, Brasil. Atlântica, v. 24, p. 97-101, 2002.
ROMERO, R. M.; MORAES, L. E.; SANTOS, M. N.; ROCHA, G. R. A.; CETRA, M. Biology of Isopisthus parvipinnis: an abundant sciaenid species captured bycatch during sea-bob shrimp fishery in Brazil. Neotrop. Ichthyol., v. 6, n. 1, p. 67-74, 2008.

RONDINELLI, G. R.; BRAGA, F. M. S.; TUTUI, S. L. S.; BASTOS, G.C.C. Dieta de Menticirrhus americanus (Linnaeus, 1758) e Cynoscion jamaicensis (Vaillant e Bocourt, 1883) (Pisces, Sciaenidae) no sudeste do Brasil, Estado de São Paulo. Bol. Inst. Pesca, v. 33, n. 2, p. 221228, 2007.

SMITH, J. W.; WENNER, C. A. Biology of the southern kingfish in the South Atlantic Bight. Trans. Am. Fish. Soc., v. 114, n. 3, p. 356-366, 1985.

UIEDA, V. S.; CASTRO, R. M. C. Coleta e fixação de peixes de riachos. pp. 1-22. In: CARAMASCHI, E.P.; MAZZONI, R.; PERES P.R. (Ed.). Ecologia de peixes de riachos. Oecol. Bras., v. 6, 1999.

VAZZOLER, A. E. A. M. Biologia da Reprodução de Teleósteos: Teoria e Prática. Maringá, PR: Eduem, 1996. $169 \mathrm{p}$.

(Manuscript received 20 October 2011; revised 20 May 2012; accepted 24 July 2012) 